Proceedings

\title{
Birds in the City-Changes in Species Diversity along Urban Gradient and Time in Krakow, Poland ${ }^{+}$
}

\author{
Małgorzata Śliż, Stanisław Broński, Izabela A. Wierzbowska and Sayantani M. Basak
}

Citation: Śliż, M.; Broński, S.; Wierzbowska, I.A.; Basak, S.M. Birds in the City-Changes in Species Diversity along Urban Gradient and Time in Krakow, Poland. Proceedings 2021, 68, x.

https://doi.org/10.3390/xxxxx

Published: date

Publisher's Note: MDPI stays neutral with regard to jurisdictional claims in published maps and institutional affiliations.

Copyright: (c) 2021 by the authors. Submitted for possible open access publication under the terms and conditions of the Creative Commons Attribution (CC BY) license (http://creativecommons.org/licenses/by/4.0/).

\begin{abstract}
Institute of Environmental Sciences, Faculty of Biology, Jagiellonian University, Gronostajowa 7, 30-387 Krakow, Poland; malgorzata.sliz@student.uj.edu.pl (M.Ś); stanislaw.bronski@student.uj.edu.pl (S.B.); i.wierzbowska@uj.edu.pl (I.A.W.); sayantani.basak@doctoral.uj.edu.pl (S.M.B.)

* Correspondence: e-mail@e-mail.com; Tel.: (optional; include country code; if there are multiple corresponding authors, add author initials)

† Presented at the 1st International Electronic Conference on Biological Diversity, Ecology and Evolution, 1531 March 2021; Available online: https://bdee2021.sciforum.net/.
\end{abstract}

\begin{abstract}
Humans transform landscapes and replace natural habitats with anthropogenic ones. Some species can adapt to these new environments, increasing their abundance and range of occurrence. To conserve the biodiversity and manage populations of organisms inhabiting cities, monitoring is required. Birds are among animals used as bioindicators of landscape and environment quality. As research on urban avifauna has become popular in the 1960s, birds are one of the beststudied urban organisms. Their communities are very dynamic and vary among different cities. The aim of our study was to evaluate changes in bird species diversity along urban gradient and time. The study was conducted in Krakow city, southern Poland, characterized by various habitats useful for many different bird species. We reviewed over 140,000 scientific records, including data from academic theses (about 750 observations), publications (100), and an official online database $(139,700)$ from the period of 1974-2020. The land use was divided into 3 zones i.e., urban, suburban, and exurban. Bird species were classified into exploiters, adapters, and avoiders, based on the adaptive behavioural traits. Also, we distinguished 3 seasons in the year i.e., winter, breeding, and migration. The total number of species observed in Krakow was 246, including 117 adapters, 103 avoiders, and 26 exploiters. There were 150 species in the breeding season, including 122 nesting ones, 199 in the migration season, and 136 in the winter. The number of species was positively correlated with the number of observations and time. Over decades, the highest increase in species abundance was observed in the exurban area. The diversity of exploiters was constant in time but an abundance of adapters and avoiders has risen. Avoiders preferred exurban areas, however, adapters and exploiters showed no differences in choice of habitat. In addition to the basic patterns of bird occurrence in Krakow along urban gradient and time, the study showed the importance of citizen science (online databases). The future data evaluation is planned.
\end{abstract}

Keywords: urban ecosystems; Krakow; diversity; birds; urbanization

\section{Introduction}

Urban ecosystems:

- humans transform landscapes and replace natural habitats with anthropogenic ones

- $\quad$ some animals can adapt to these new environments, increasing their abundance and range of occurrence.

Birds in the city:

- $\quad$ one of the best-studied urban groups of organisms

- used as bioindicators of landscape and environment quality

- $\quad$ studies became popular in the 1960s - growing interest 
(Marzluff et al. 2001, Chace \& Walsh 2004).

\section{Aim of the Study}

Evaluation of changes in bird species diversity along urban gradient and time.

\section{Research Questions}

How does urban gradient affect the occurrence of different groups of birds?

How did bird communities change over the last 60 years in Krakow?

\section{Methods}

General method: a scientific review.

\section{Study Area}

A study was conducted in Krakow, Poland (Figure 1).

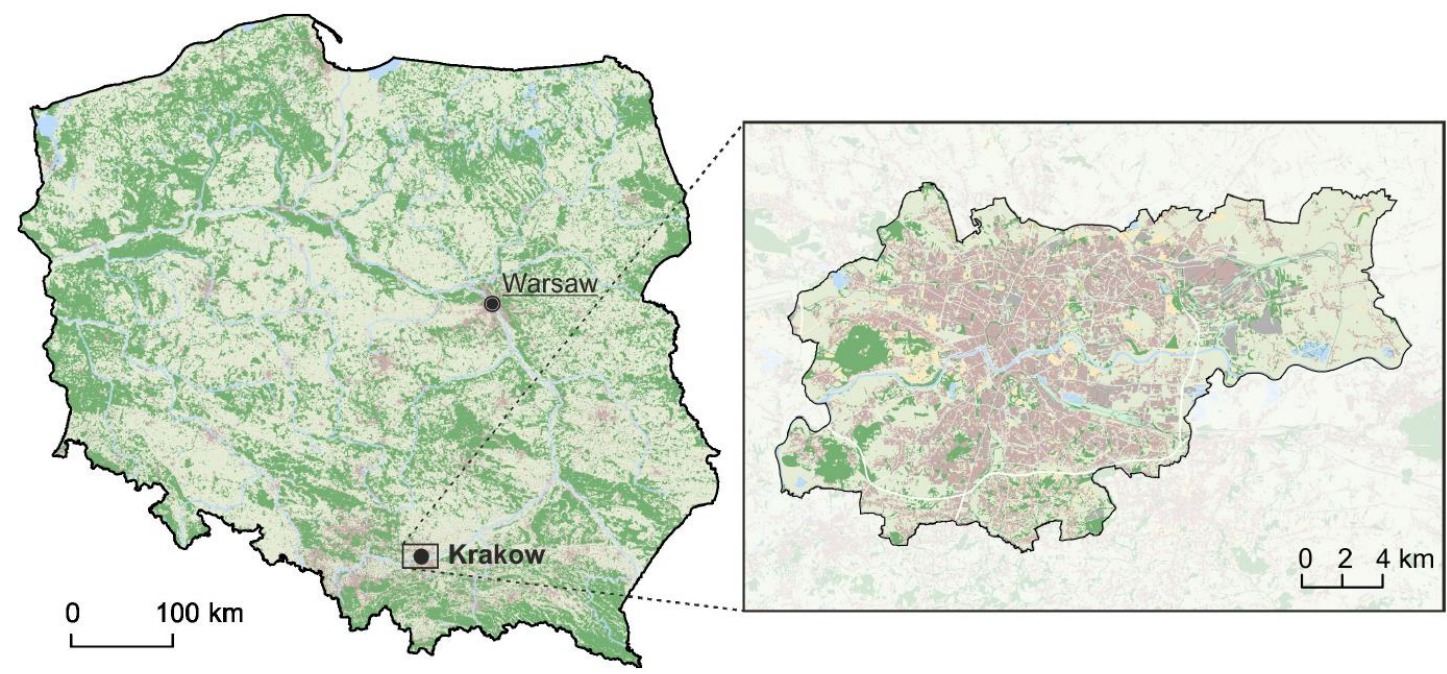

Figure 1. Location of the study area (Basak et al. 2020).

Basic information:

- $\quad$ second largest city in Poland

- $\quad$ population of 775,000

- $\quad$ population density of $2384 / \mathrm{km}^{2}$

- $\quad$ area of $327 \mathrm{~km}^{2}$

- $\quad$ diversified land cover (Figure 2)

- Vistula river - natural migration corridor (Urząd Statystyczny w Krakowie). 


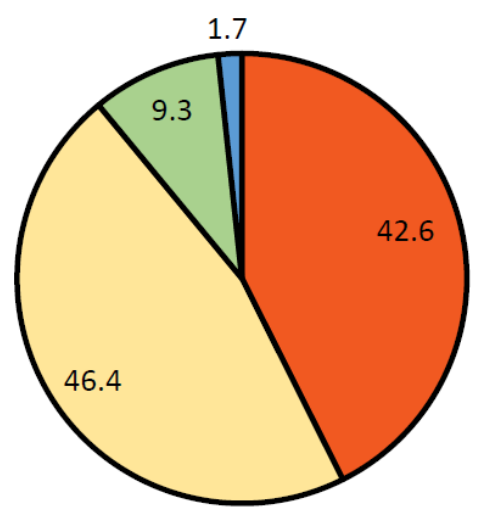

\section{口Urban area $\quad \square$ Agricultural area $\square$ Green area $\quad \square$ Water bodies}

Figure 2. Percentage of different types of landcover in Krakow (based on Chełstowska \& Filip 2009, UMK. BIP-MK).

\section{What Was Reviewed?}

Over 140,000 scienific records, including:

- academic theses - about 750 observations

- publications-about 100 observations

- $\quad$ an official online database Ornitho.pl-about 139,700 observations from the period of 1974-2020.

\section{Types of Land Use}

Table 1. Landscape of settlement descriptors.

\begin{tabular}{cccc}
\hline Term & Percentage Built & Building Density & Residential Human Density \\
\hline Wildland & $0-2$ & 0 & $<1 / \mathrm{ha}$ \\
Exurban & $5-20$ & $<2.5 / \mathrm{ha}$ & $1-10 / \mathrm{ha}$ \\
Suburban & $30-50$ & $2.5-10 / \mathrm{ha}$ & $>10 / \mathrm{ha}$ \\
Urban & $>50$ & $>10 / \mathrm{ha}$ & $>10 / \mathrm{ha}$ \\
\hline
\end{tabular}

Division based on Marzluff et al. 2008. 


\section{Urban Wildlife Categories}

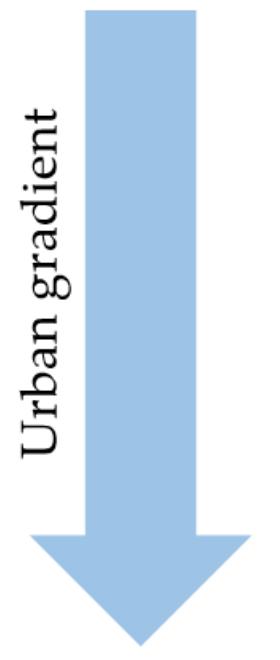

\section{Avoiders}

- highest densities in natural habitats

\section{Adapters}

- high densities in natural and suburban habitats, thrive in urban areas

\section{Exploiters}

- highest densities in urbanized areas, rare in natural habitats

Division based on the adaptive behavioural traits (Adams et al. 2006, Urban Wildlife Group 2012).

\section{Avoiders}

- avoid people and urban areas

- sensitive to human-induced changes in the landscape

- visit cities occasionally, often during migration or winter season
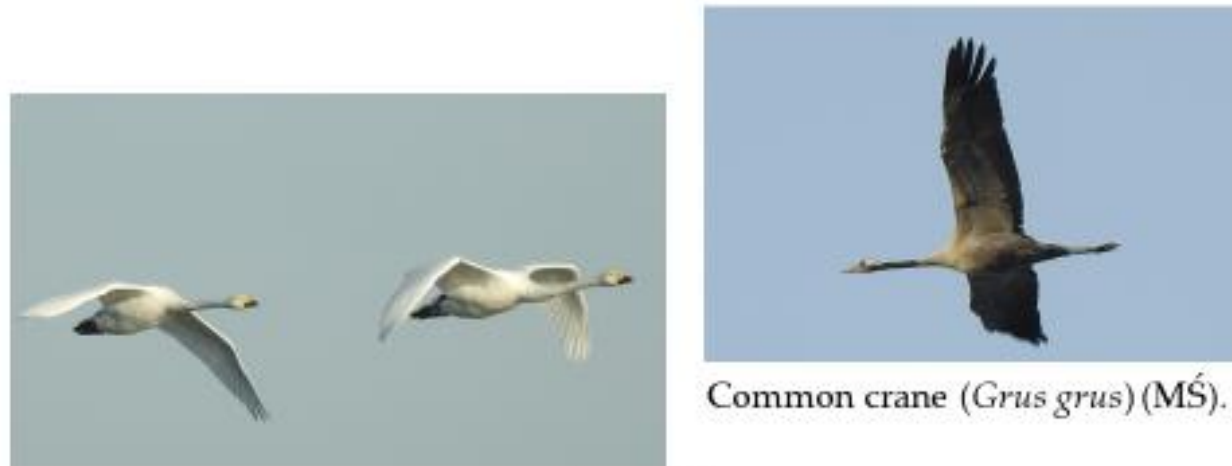

Common crane (Grus grus) (MŚ).

Whooper swan (Cygnus cygnus) (photo MŚ). 


\section{Adapters}

- thrive in the cities

- prefer exurban and suburban areas, especially older, residential districts
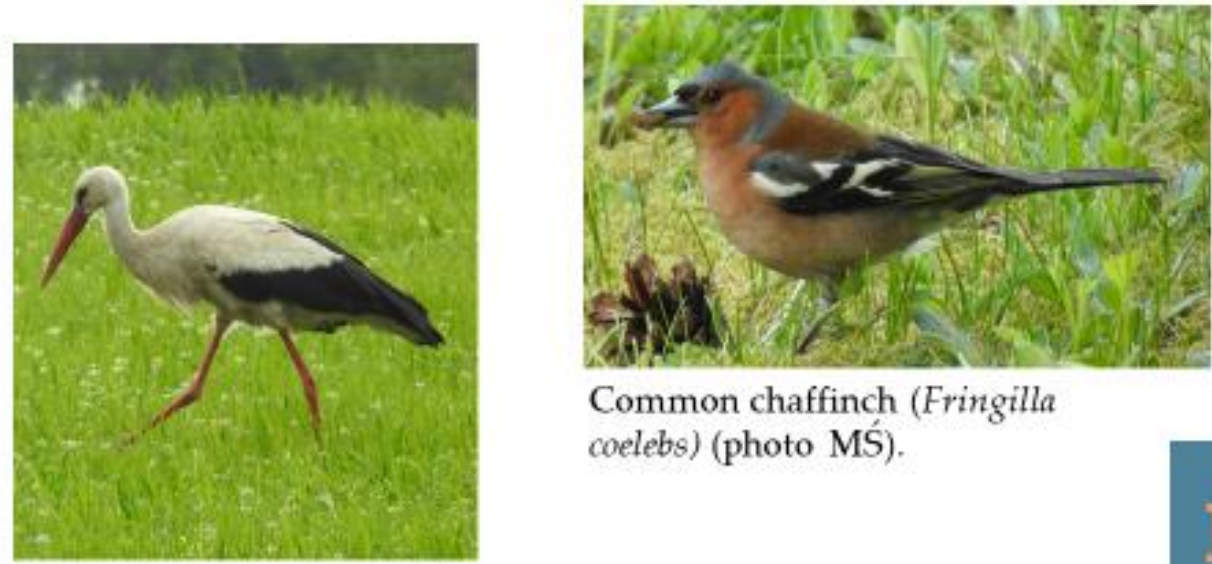

Common chaffinch (Fringilla coelebs) (photo MŚ).

White stork (Ciconia ciconia) (MŚ).

\section{Exploiters}

- achieve higher numbers and population densities in urban than natural areas

- often generalists, can utilize anthropogenic resources

- only a few species

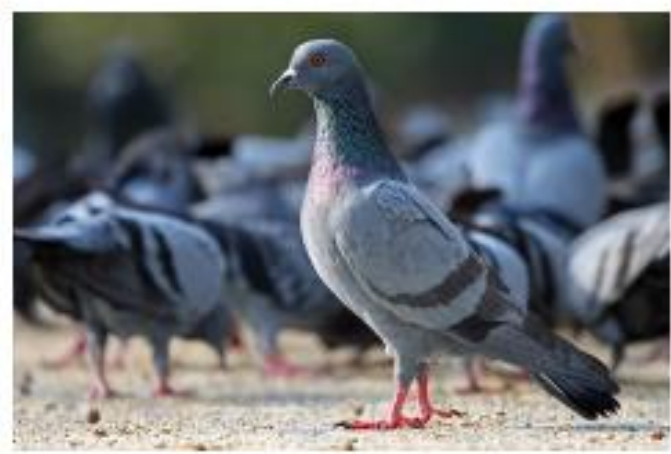

Feral pigeon (Columba livia f. urbana) (Wikimedia $\mathrm{CH}$ ).

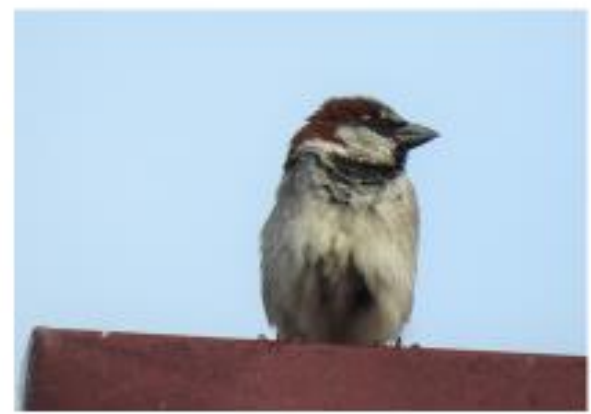

House sparrow (Passer domesticus) (MŚ). 


\section{Seasons in the Year}

There are three main seasons in the year:

\begin{tabular}{c|c|c|c|c|c|c|c|c|c|c|c|c|} 
Dec & Jan & Feb & Mar & Apr & May & Jun & Jul & Aug & Sept & Oct & Nov & Dec \\
\hline & & & & & & & & & & & \\
Winter & \multicolumn{3}{c}{$\begin{array}{c}\text { Breeding season } \\
\text { (spring and summer) }\end{array}$} & \multicolumn{3}{c}{$\begin{array}{c}\text { Migration } \\
\text { (autumn) }\end{array}$}
\end{tabular}

* there is also a spring migration, which happens between winter and breeding season, usually not distinguished in analyses.

\section{Results and Discussion}

$1974-2020$
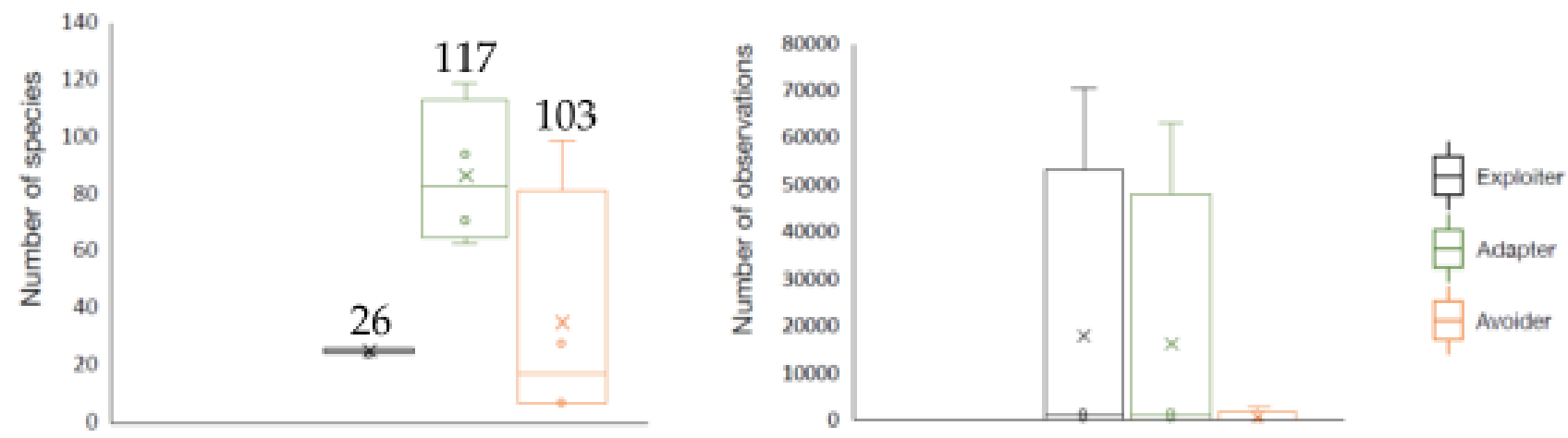

Figure 3. Number of species and observations in each bird category in 1974-2020 (mean and the total number).

In total 246 bird species, including 122 nesting ones.

The total number of species and observations was increasing over time. 


\section{Avoiders in Krakow}

Birds from different taxonomic groups.

Many of them observed only once or twice in the analysed time period.

Two of the most common species showed in photos.

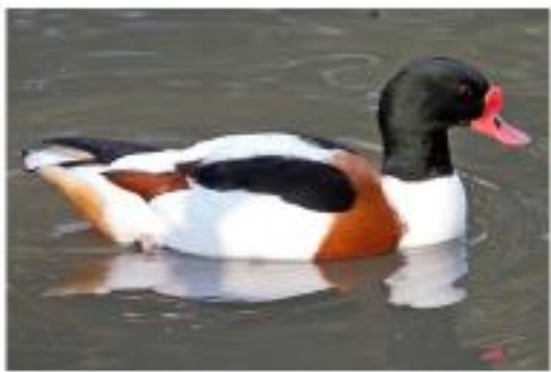

Common shelduck (Tadorna tadorna) (Adrian Pingstone).

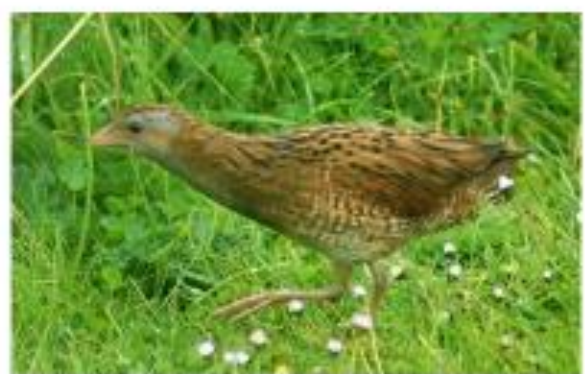

Corn crake (Crex crex) (Rachel Davies).

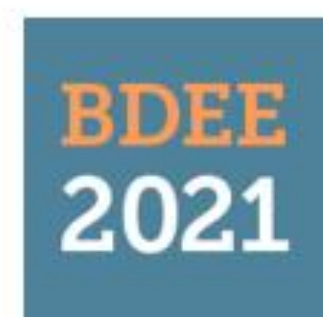

\section{Adapters in Krakow}

Most diversified and species-rich group. Birds from different taxonomic groups, usually small passerines. Many water birds.

The three most common species showed in photos.

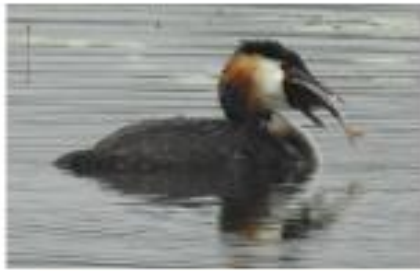

Great crested grebe (Podiceps cristatus) (MS).

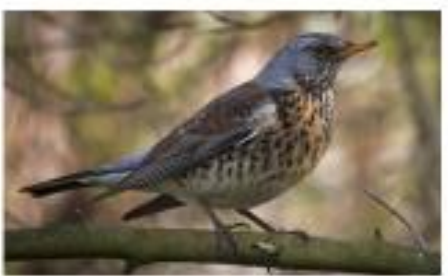
(hedera.baltica).

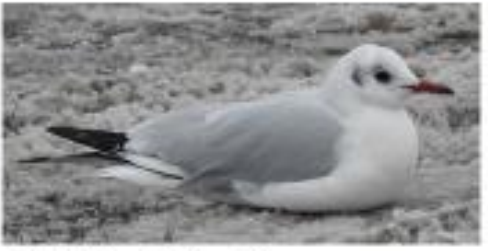

Black-headed gull (Chroicocephalus ridibundus) (MŚ).

Fieldfare (Turdus pilaris)

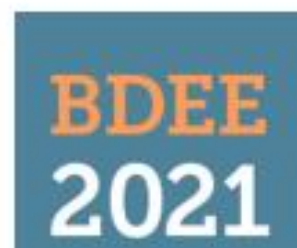




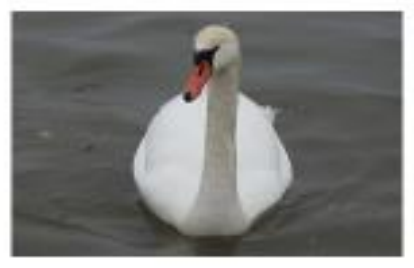

Mute swan

(Cygnus olor)

(MS).

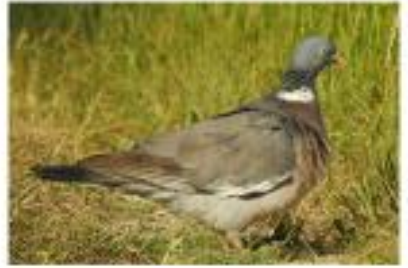

Common wood pigeon (Columba palumbus) (MŚ).

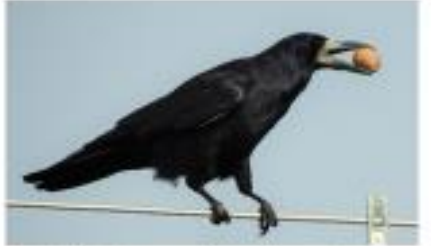

Rook (Corrus frugilegus) (MŚ).

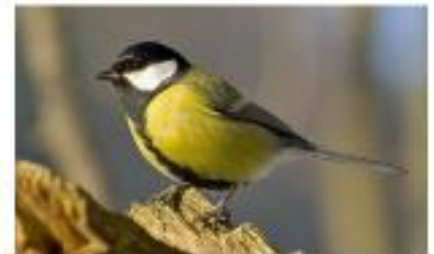

Great tit (Parus major)

(Stawomir Staszczuk).

\section{Exploiters in Krakow}

Mainly representatives of three orders:

- Anseriformes (ducks, waterfowl)

- Columbiformes (pigeons and doves)

- Passeriformes (especially Corvidae)

The highest numbers of individuals. The four most common species showed in the photos.

An increase in the species diversity of adapters and avoiders. The number of species of exploiters remained constant (Figure 4).

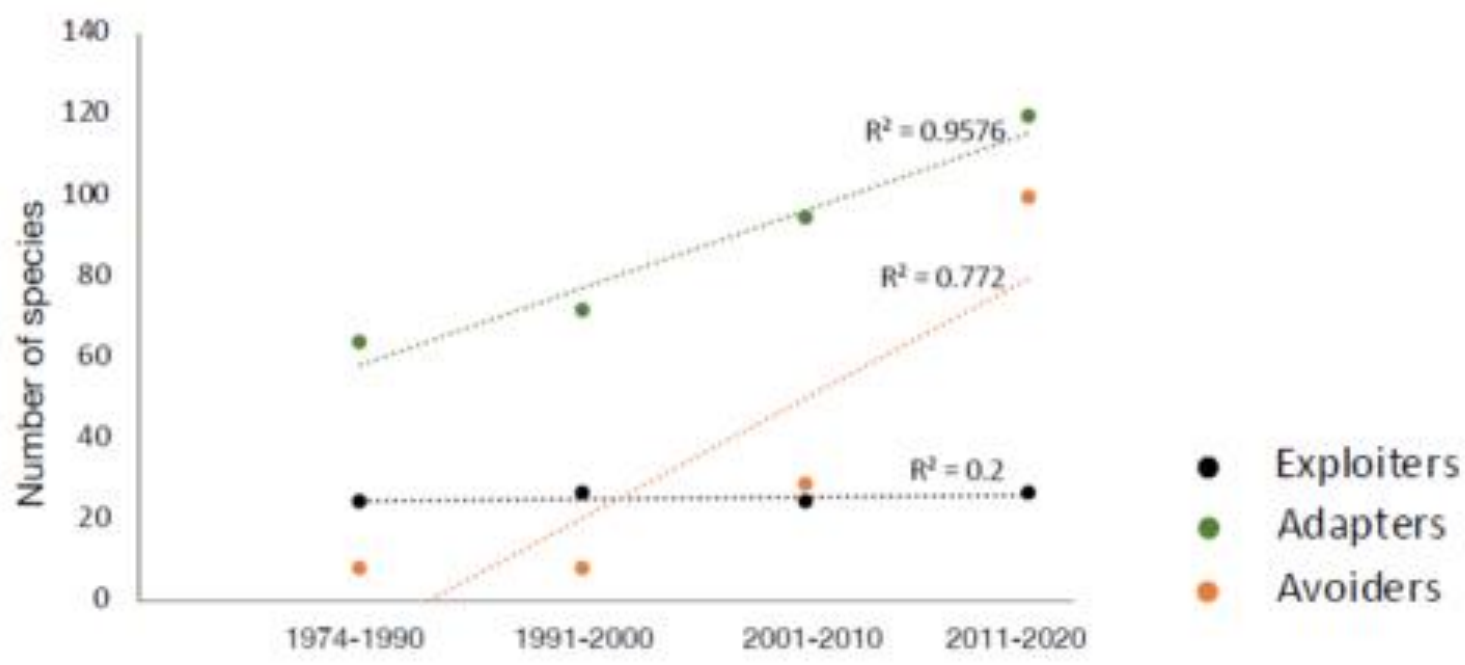

\section{Decades}

Figure 4. Number of species in each bird category over decades (the total number and linear regression).

The number of species increased in all types of urbanised areas.

At the beginning of the study, the number of species was the highest in urban areas and then constantly grew. In the case of exurban and suburban areas, bird species numbers started to increase since the 1990s. This may be partly explained by the varying activity of observers in particular zones (Figure 5). 


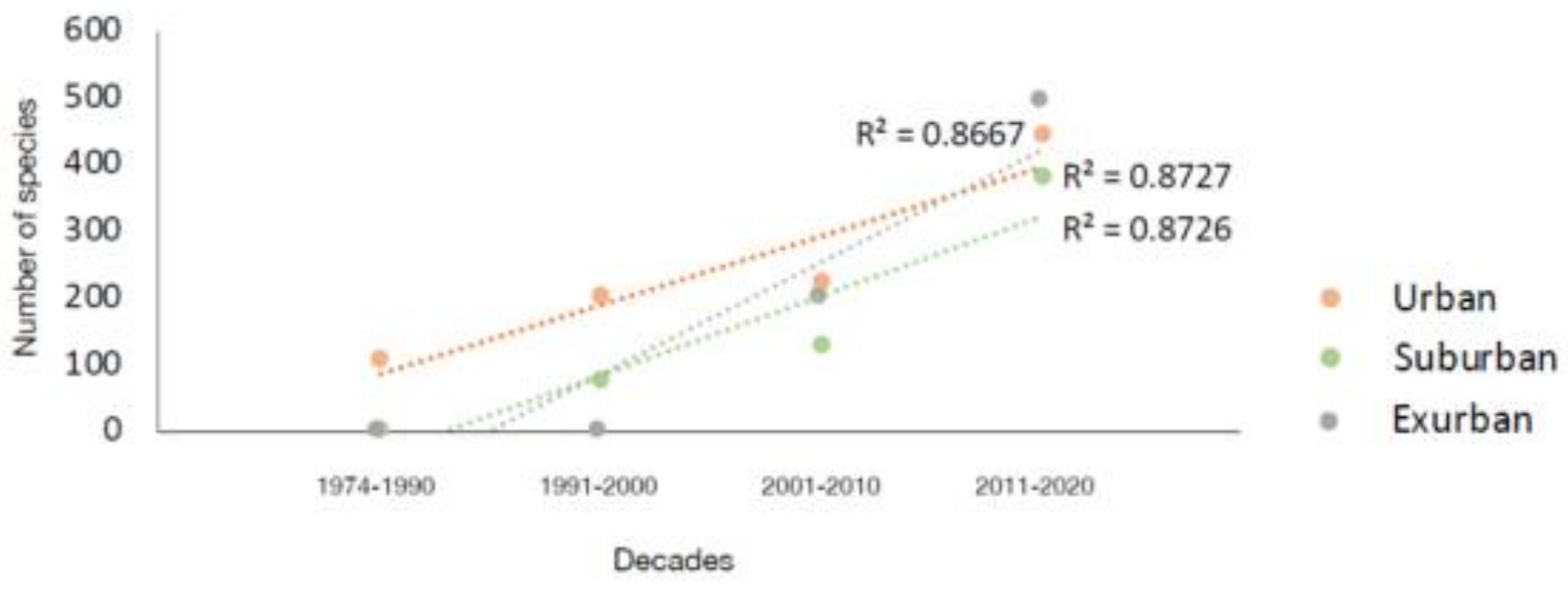

Figure 5. Number of species in each category of land use over decades (the total number and linear regression).

Much higher number of species of avoiders in an exurban area than in the other ones (Figure 6).

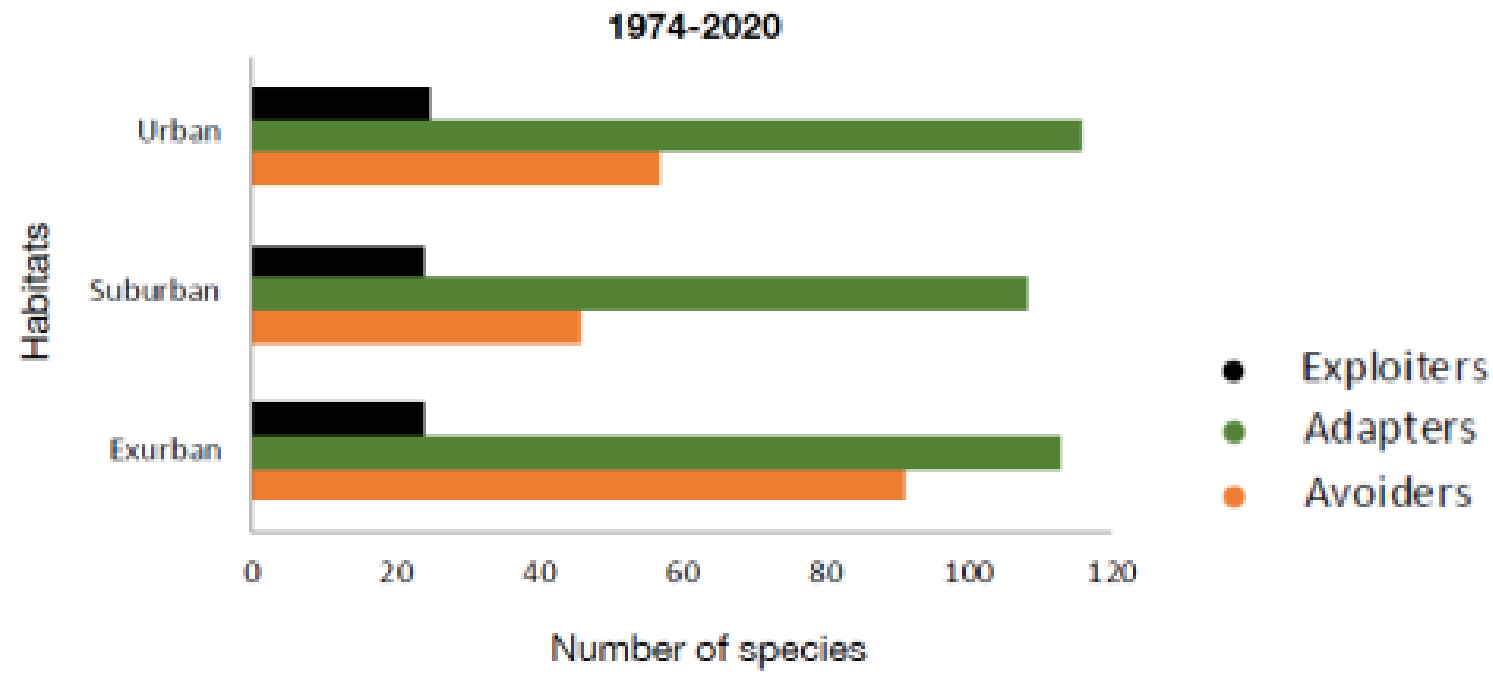

Figure 6. The total number of species in each bird category in different types of land use (habitat).

\section{Summary and Conclusions}

- number of species in Krakow is increasing over time

- high increase in the species diversity of avoiders and adapters, constant species composition of exploiters over decades

- exploiters are the most common birds observed in the city

- avoiders prefer exurban areas, other groups show no differences in choice of habitat

- small number of publications about urban avifauna in Poland

- online data bases are an important source of information about species abundance and occurrence in the 21st century

- $\quad$ significance of citizen science (online databases)

- future data evaluation is planned.

Institutional Review Board Statement:

Informed Consent Statement:

Data Availability Statement: 
Acknowledgments: Special thanks to Tomasz Chodkiewicz, the administrator of the online database Ornitho.pl (https://www.ornitho.pl/ (Polish site)) for providing data.

\section{ORNITHO.PL}

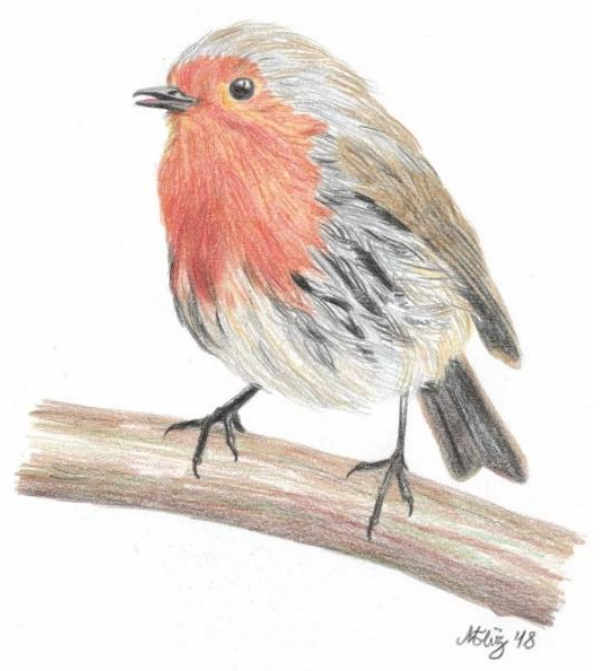

European robin (Erithacus rubecula), a common adapter species (MŚ).

\section{References}

1. Adams, C.E.; Lindsey, K.J.; Ash, S.J. Urban Wildlife Management; Taylor \& Francis Group: Boca Raton, FL, USA, 2006.

2. Basak, S.M.; Wierzbowska, I.A.; Gajda, A.; Czarnoleski, M.; Lesiak, M.; Widera, E. Human-Wildlife Conflicts in Krakow City, Southern Poland. Animals 2020, 10, 1014. doi:10.3390/ani10061014

3. Chełstowska, A.; Filip, R. Krakow in Numbers 2009; The Municipality of Krakow, A City Strategy and Development Deaprtment: Krakow, Poland, 2010; p. 56.

4. Marzluff, J.M.; Bowman, R.; Donnelly, R. A historical perspective on urban bird research: trends, terms, and approaches. In Avian Ecology and Conservation in an Urbanizing World; Marzluff, J.M., Bowman, R., Donnelly, R., Eds.; Springer: Boston, MA, USA, 2001, doi:10.1007/978-1-4615-1531-9_1

5. Marzluff, J.M.; Shulenberger, E.; Endlicher, W.; Alberti, M.; Bradley, G.; Ryan, C.; ZumBrunnen, C.; Simon, U. (Eds.) Urban Ecology, an International Perspective on the Interaction between Humans and Nature; Springer Science+Business Media, LLC.: Berlin/Heidelberg, Germany, 2008.

6. UMK (Urzad Miasta Krakowa [Municipality of Krakow]) Raporty o Stanie Miasta - Biuletyn Informacji Publicznej Miasta Krakowa-BIP MK. Available online: https://www.bip.krakow.pl/?id=509 (accessed on 14 May 2020).

7. Urbanlife Working Group (2012). Available online: http://urbanwildlifegroup.org/ (accessed on).

8. Urząd Statystyczny w Krakowie. Vademecum. Available online: https://krakow.stat.gov.pl/vademecum/vademecum_malopolskie/portrety_miast/miasto_krakow.pdf (accessed on 27 February 2021) 